\title{
Futurists at the Front. Bloodless Murder Magazine and First World War
}

\author{
Alexandra Strukova \\ State Institute for Art Studies \\ Moscow, Russia \\ E-mail: alexandra.i.strukova@gmail.com
}

\begin{abstract}
The article is devoted to the history and artistic features of the avant-garde "Bloodless Murder" magazine. During the First World War it was published by the literary and artistic group, united around Mikhail Le-Dantiu and Olga Leshkova in Petrograd. Issues of the magazine from the collection of the Russian State Archive of Literature and Arts in Moscow studied in such details for the first time.
\end{abstract}

Keywords-Russian avant-garde; Futurism; "Bloodless Murder” Magazine; Mikhail Le-Dantiu; Ilya Zdanevich

\section{INTRODUCTION}

"There is a story to the name of the publishers. Bloodless Murder appeared long before the war and the use by the Germans of asphyxiating, stinking gases is nothing short of lowly plagiary, for which this abominable nation will be brought to account in due time. There is no point in changing the name of an old and respectable firm only to avoid insulting comparisons whipped up by obvious jealousy and malice", [1] wrote in one of the issues Olga Leshkova, the author of most of the texts in the magazine. The origin of that name has remained a mystery: Leshkova said nothing relevant in an explanatory note she drew up in the 1930s, when handing over papers on her literary activities to the archive. Antonina Zainchkovskaya suggested that the name had had mundane underpinnings and had been borrowed from St Petersburg's criminal chronicles. [2] Sulfuric acid attacks in revenge for unfaithfulness became quite common in the early $20^{\text {th }}$ century, and the press called one such case "bloodless murder" (the case of Vera von Vick). [3]

Although the magazine foundation date is unknown, it was most likely 1915 . Despite the wartime circumstances, its "exotic and 'shocking"" [4] name, to quote Leshkova, had to do with the daily life of a big city (true, in its extreme manifestations) and the existing avant-garde tradition. Mikhail Le-Dantiu, an artist, avant-garde theorist, follower of Mikhail Larionov and contributor to a number of exhibitions the latter organised in the 1910s, was the magazine editor and inspirational figure. The choice of that provocative name with criminal implications is largely reminiscent of Larionov's "Knave of Diamonds" (the phrase meaning a swindler, the Ace of Diamonds referring to a tab on the convict's back), the only difference being its preponderant black humour and the avant-garde principle "the worse the better" brought to the limit.
There was nothing ominous in the magazine itself. What was more, compared to the wartime deprivations and horrors experienced by the "bloodless murder" artists doing army service in the field, at the frontline, and by their co-authors in Petrograd, the tone of the publication was surprisingly lightminded.

The magazine came about inadvertently: it was born of friendly home entertainment of the type of competition for the worst poetry. The first issue had no title and most likely served as an invitation to a party thrown by the journalist, philologist and collector Janko Lavrin that was attended by young people of versatile gifts. Apparently, it was in connection with that invitation that the founders of the magazine hit upon a form that they were to stick to subsequently: a hectograph drawing accompanied by typewritten commentary. The contributors of drawings and texts changed subsequently, but the first issue was entirely the work of Le-Dantiu, the central figure of that coterie of friends. It was also noteworthy that his death marked the end to the publication.

\section{ARTistic FeAtURES OF THE MAGAZINE, ITS EMPLOYEES}

Starting with the first issue, momentous and insignificant events in the lives of Leshkova's and Le-Dantiu's friends were in the focus of attention. The contributors aimed at the theatricalisation of daily life and bohemian play-acting. They presented a gallery of their acquaintances in sundry roles. In issue 5 of the Bloodless Murder Leshkova called herself the "publishers' emcee". [5] Patently tongue-in-cheek tricks, mystifications, fake biographies, invented images of authors and their relevant works were common practice in the St Petersburg literary quarters. With the Bloodless Murder those tricks were undisguised, their fantasies so grotesque and hints so unequivocal that one could make no mistake about them. Issue 5 asked prospective contributors to supply their life stories: "It would be worse if the editors themselves come up with the requisite biographies. The editors never check out bios supplied by contributors". [6] Nicknames current in the group or thought-up specially for the magazine were quite common: "Velvet" Kolya was the philosopher writer Nikolai Belotsvetov (No. 1); "Eternal Traveller" Janko Lavrin (No. 1); Nikolai Yankin was nicknamed "Mr. Kokoyankin, a young talented artist, "who enjoyed well- 
deserved popularity and overwhelming success on Tierra del Fuego" (No. 5); Roza Levinson was "the tyro poetess Monna Roza Levinsonda" (Nos. 7, 8); "Magoma-Lapshi-Oglu" was Nikolai Lapshin, who had fought in the Savage Division (Nos. 8, 14); Vera Yermolayeva appeared in two hypostases: as "a pure Assyro-Babylonian young girl" in an "ancient" picture and as an archaeologist of Baghdad, Yermolai Yermolayevich Yermolayev, who had sent it to the editors (No. 10). On one occasion Le-Dantiu was "the evil Assyrian deity Maskim" (No. 10), on another he was referred to as "a staff worker hailing from the Fiji Islands, yutnaD'eLem (No. 6 ), or else as "the honorary editor Yutnadel" (No. 8).

Le-Dantiu contributed drawings and texts, Leshkova wrote most of the texts, the artists Yermolayeva, Lapshin and Yankin did drawings, and the poet Levinson contributed poetry. Yekaterina Turova, too, did drawings that remained unpublished. [7]

The magazine readership and fans, as well as persons mentioned in it formed a far wider circle. In her explanatory note to Issue 17 Leshkova wrote, "On the right (of a magazine drawing) the Bloodl $<$ ess $>$ Mur $<$ der $>$ 'blackboard' - people who insisted on the Bloodl<ess $>$ Mur $\langle$ der $>$ monthly issue, but failed to contribute: Monna Roza, the artist V.A. Kuznetsov, E.I. Gurzhienko, who had promised to compose The Cow Melancholy waltz, M.A. Kuznetsova, the composer B.F. Lidtke, the archaeologist Nik.<olai> Ant.<onovich> Ivanov". [8]

They were texts for the insiders, which formed a narrative that now and then made reference to preceding or following issues, brought to mind something commonly known and brimmed with in-jokes or those referencing themes discussed in the group.

\section{MILITARY AND ARTISTIC REALITIES REFLECTED IN MAGAZINE}

The make-believe principle was commonly used. Thus, Issue 5 stated: "the subject and theme do not matter, any subject and any theme become worthwhile as soon as bloodless murder touches upon them". Spying from round the corner was another principle used: "The life of every person can be considered without any point of view, from a certain angle and from round the corner. We have decided to opt for the latter method". [9]

Slogans and clichés came galore: "Europe has gone rotten", "We should learn from the savages" (No. 6), "freedom above everything else" (No. 7), "interaction between man and the environment" (No. 8), "uses with rare dynamic energy" (No. 8). These were again in-jokes because extracts from oral and written pronouncements of the representatives of new art were put into an absurd context. Such self-ridicule was rare in Russian Futurist practice.

The hectograph Bloodless Murder publications were quite in line with Futurist books that consciously cultivated non-professionalism and amateurishness. The Futurists learned to combine the verbal and the pictorial language as was characteristic of lubok prints (Le-Dantiu knew well the published Rovinsky collection of luboks). However, stylistically Bloodless Murder drawings were often a far cry from lubok prints.

In their topicality and registration of mundane details and in general certain temporal features drawings by Le-Dantiu, Lapshin and Yankin were closely related to the satirical magazines published in Russia primarily in St Petersburg/Petrograd (such as Satyricon, The New Satyricon and Bich). Stylistically, their drawings could be slightly Cubist-like or reminiscent of Style Moderne graphic works, or else quite neutrally realistic in the spirit of most of illustrations to satirical magazines of the capital.

Like the Satyricon, the Bloodless Murder produced "personalised" issues. Those of the Satyricon focussed on Nikolai Gogol, Leo Tolstoy and Boris Suvorin, and the "murderers" following in its footsteps was meant to create a humorous effect. The "Assyro-Babylonian Issue" (No. 10) of the Bloodless Murder in its tone and tongue-in-cheek theme referenced the Universal History as Represented by the Satyricon, for which Teffi wrote the Ancient History section in 1910.

In their correspondence Leshkova and Le-Dantiu frequently mentioned satirical magazines published in Petrograd. For instance, they recorded the regular dispatches of the Satyricon, [10] the Bich, [11] as well as the Ogonyok magazine and the Vecherny Petrograd [12] newspaper to the frontline. In January 1917, Leshkova sent the New Satyricon Vestnik znaniya [13] supplement to Le-Dantiu.

The fact that, after the Satyricon editors split and the most gifted contributors left in 1916, its managers suggested that the Bloodless Murderers cooperate with the Satyricon is further proof of the two magazines' kinship. Proposed to contribute two pages to every Satyricon issue, the "murderers" declined: all of their artists were at the front while Leshkova did not consider herself a professional writer. [14]

Although she managed the literary part of the magazine brilliantly, she had no aspirations of a serious writer and showed no jealousy when Ilya Zdanevich borrowed the plot and characters from the Albanian Issue for his zaum' drama Janko Krul albanskii. Leshkova described her response to Zdanevich's criticism of her text in a letter sent to Le-Dantiu at the frontline in December 1916: "I have quite sincerely agreed with all the criticism $\langle\ldots\rangle$, I have absolutely no literary aspirations, and if producing a regular issue of Bloodless Murder I roll my eyes and say that 'literature is my life', I do this exclusively with the aim of shaking the air with thick purple ringing". [15]

Dmitry Sarabianov observed that Russian Futurism "set the war theme into a historical perspective" (Lyubov Popova, Aristarkh Lentulov) or "turned to the mythologised image of war" (Pavel Filonov, Natalia Goncharova, Olga Rozanova). [16] The Bloodless Murder demonstrated yet another approach: wherever they were, be it a military school or a hospital after sustaining a wound, self-irony was always there. Whatever the circumstances, they continued playing games, but knew where to draw the line: I think it was no accident that neither Le-Dantiu, nor Lapshin depicted actual 
battle scenes or the killed as such, or that Leshkova never let her wit venture into the theatre of operations. These themes were passed over in silence to such an extent as to seem nonexistent. It was impossible to play the fool gleefully on that material, so the editors accepted the war as a given and at the same time ignored it. To my mind, they saw it as a misunderstanding that interfered with the course of creative life. Even in her private correspondence Leshkova almost never complains (save for daily harships) or succumbs to despondence and stoically endures all the vicissitudes of "our sticky, dumb and stupid time”. [17]

Nevertheless, many members of the group sought, to quote Lapshin, "somehow to take part in the common cause". [18] Le-Dantiu served in the $416^{\text {th }}$ Verkhne-Dneprovsky infantry regiment. [19] In 1916 Zdanevich worked as a correspondent in the Caucasus Army, from December 1916 as a secretary at the Severnye zapiski magazine, [20] and after the February 1917 Revolution he was assistant head of the state defence detention department of the State Duma. Lapshin volunteered for the Caucasus Native Cavalry Division (the Savage Division), was wounded at the frontline and then was slowly evacuated to Petrograd, where he was treated and lived a quiet civilian life, occasionally going to the Luga military hospital for medical checkups. He was transferred as a decorator artist to the Grenadiers Regiment.

The wealth of toponymics in the names of magazine issues may have been the imprint of the wartime period, the editorials reported about frontline developments and listed sundry geographical names connected with the theatre of military operations. It was a parody of sorts, all the more so since in the majority of cases the magazine wrote not about Albania or Daghestan, but about imaginary (or mostly imaginary) events in the lives of its "highly gifted staff members".

Leshkova's circle had existed from early 1913. At about that time its members met Velemir Khlebnikov: "To entertain him a bit, I rather unsuccessfully took him on several occasions to parties given by my friends. Even at Olga Ivanovna Leshkova's, a merry and witty friend of the artist Le-Dantiu whose flat was frequented by young artists and men of letters (Mikhail Le-Dantiu, Nikolai Lapshin, Ilya Zdanevich and others), he sat as if in a brown study and cared little about meeting new people". [21]

\section{Magazine Publishing Features, Some of ITs ISSUES}

Initially, it was the publishers that was called Bloodless Murder and its products were not numbered. Evidently, the issues were "back-numbered". In her letter to an unknown addressee Leshkova explained: "I'm writing to you on the latest 'edition' of our Bloodless Murder publishers [22] (No. 4); Issue 5 makes use of the following expression: 'works put out by the publishers'. ("The publishers has the rule that comments on and reviews of works put out by the publishers be written by the authors themselves. This cuts the workload of the editors and saves the authors all sorts of mishaps [23]). It was not until Issue 6, 1916, about the Fiji islands that the word "magazine" was used. [24]
The Albanian Issue stated that the publishers had started with the publication of a collection of verses, Lakhudra (Skank), dedicated to J.I. Lavrin. Next came an Illustrated Notice/Invitation to a "Rout" Given by the Journalist Janko Lavrin (No. 1). The second and third issues are absent from the corpus of papers transferred by Leshkova to the archive. [25]

Issue 4 of Bloodless Murder came out not later than 15 October 1915 and had only drawings without any text. A caricature self-portrait of Le-Dantiu carried by it dated from the time of his studies at the Vladimirsky Infantry School. "The military cadets led a fairly quaint life at school. They are allowed out quite dressed up, but inside the school and during the manoeuvres, when they have to carry out prereconnaissance, crawl through ditches and walk on all fours in the puddles, they are dressed as shown in the caricature," Leshkova quoted Le-Dantiu. [26] The repetitive figures bring to mind the notion of rhythm that Le-Dantiu considered crucial [27] and attest to the significant decorativeness of his works (he referred to the task faced by the painter as "ornamentation", using the expression the "ornamentation of the war" in his letter to Lapshin [28]).

The following issue of Bloodless Murder - In the Rear, No. 5, 1915 - carried on the war theme. Nikolai Yankin, aka Mr. Kokoyankin, contributed two drawings to it. Both dealt with the burning problems of life in the rear: convalescing wounded soldiers, nurses, and women who had taken up the jobs of recruited men. The drawing named The $79^{\text {th }}$ shows one of the women conductors, who first got access to that type of man's job in 1915 for lack of hands. Yankin's drawings are executed professionally in a sure hand; as an applied artist (a graduate of Baron Alexander von Stieglitz's School of Technical Drawing), he pays special attention to balancing the representation and inscription, invariably including the latter into the sheet space. Both thematically and pictorially, precisely his drawings come closest to the tradition of satirical magazines. The tram theme, in particular a woman passenger finding it difficult to hold onto the handle hanging from the car ceiling, was very popular with the selfsame Satyricon. Yankin jokes exclusively on everyday themes and shuns ironical statements à la LeDantiu on the struggle of old and new art. However, in the manner of execution - linear drawing with hatching - he works in line with the drawing practiced by Le-Dantiu. Yankin emulates not only his colleague in Bloodless Murder, but also the anonymous caricaturist from the Bich magazine, which was published in Baku in the 1910s. He borrows the right figure in his drawing In the Rear from the caricature Coming from an Exam, [29] turning a grammar-school uniform into a baggy soldier's overcoat. Having thus whipped up his imagination, he was not quite a success in arranging two characters strictly in profile and one full-face. The nurse - a Venus in furs - is leading a procession of maimed soldiers and frankly flirting with them. This joke is a little too risky for the wartime Russian press, as Leshkova points out in her text: Kokoyankin "enjoys well-deserved popularity and such an overwhelming success on Tierra del Fuego, to depicting whose way of life this talented young artist has devoted his work, the artist who due to his modesty 
(typical in general of all big talents) did not want to bother the Russian censors with his works...". [30]

The fashionable theme (especially in Symbolist and Acmeist poetry) of exotic islands appeared in Issue 6, 1916, focusing on the Fiji islands. As distinct from the simplehearted Yankin, whose drawings Leshkova did not deem necessary to comment upon ("all we can do is to be silently proud of having such a colleague"), that issue brought into play not only the wartime queues but also statements by lecturers on Futurism. The artist from Fiji solves the food supply problem by making mincemeat of the St Petersburg public, which is unable to tell the top from the bottom in his pictures and is literally smitten by his art. The public drops right into the mincing-machine. "This first experience of applying an artistic emotion to the food problem is of tremendous success." The two contributors - Le-Dantiu with his drawings and Leshkova with her comments paradoxically wedded the daily life themes, which the caricaturists had well developed, [31] to the Futurists' selfirony.

\section{NiKOlai LAPSHIN IN "BlOODLESS MURDER"}

In the autumn of 1915 Lapshin left for the front. At first, he had a somewhat romantic attitude to the army and the war: he was after an adventure in a bid to escape the "soldiery". After an unsuccessful attempt to enrol in a flying school (he was rejected because of short-sightedness) Lapshin joined the Savage Division. He may have served in the Second Daghestani Regiment, as is suggested by the name of the Daghestani Issue (No. 8). In his drawing Le-Dantiu showed Magoma-Lapshi-Oglu, who had mastered the customs of the Savage Division and stolen silver spoons as his fee for contributing to the magazine. Even though a part of the picture was slightly deformed in the spirit of the latest fashion, overall the drawing was akin to the satirical magazine graphics. Portrait resemblance of all the characters and the exaggerated expressiveness of their mimics bring this sheet close to caricature, for example, to Alexei Radakov's illustration for the New Satyricon. [32] The drawing shows Lapshin, Le-Dantiu, Leshkova and Levinson.

Speaking of the war theme, the uniform of MagomaLapshi-Oglu is worth noting. He is wearing a Circassian coat with cartridges, his chest decorated with Orders: two Albanian Orders, including the Order of the Free Throne; a Fiji Order of the Dead Piglet (commemorating the abolition of "artistic truth" in art) and the Order of the Green Horse for merit in cavalry art.

Strange as it may seem, the Bloodless Murder witticisms had a precedent. Journalist N.N. Breshko-Breshkovsky, the author of frontline reports and of the book The Savage Division, wrote that "the incompatible was combined" in the division: "For the first time in the history of Russian military uniform one could see Circassians of the Caucasus wear 'naval' shoulder-straps". [33] "The horsemen thought highly of military awards; however, when receiving a cross, they invariably insisted that the award 'had not birds, but the Dzhigit' as the highlanders referred to the mounted St. George." [34]
The same issue carried two drawings of Lapshin himself. One showed a Savage Division horseman with an inscription: "Spear, sword and dagger hold 'em all in one hand". Even in his young years (when he attended M.D. Bernstein's studio) Lapshin was famous for his excellent drawings. But this work of his is surprising with strangely stiff lines and rigid drawing. As was always the case with Lapshin, he tried to follow examples of the selfsame New Satyricon that were alien to him. Apparently, he tried to assume the jocular tone accepted in the Bloodless Murder milieu and to emulate drawings that the company liked. If pictures of the daredevil Cossack Kozma Kriuchkov were popular with the peasants of the wartime period, the readers and artists of the New Satyricon fancied another image of a brave WWI soldier - a mounted highlander. V.V. Lebedev, D.I. Mitrokhin, monogrammist $\mathrm{N} \mathrm{K}$ and other artists drew the highlander. [35] The reason for the popularity of the latter was the military success of the selfsame Savage Division covered in the press. In 1915, the Niva magazine published BreshkoBreshkovsky's feature "Caucasian Aces in Galicia". It was to Galicia that Lapshin set out after being enrolled in the regiment.

Issue 14 of Bloodless Murder was named the Galician Issue: in it, Lapshin showed the lifestyles of the people inhabiting that area. The "bloodless murderers" all shared an interest in Eastern Europe and Janko Lavrin published the "Slavic Collections".

Lapshin committed to paper not only the typical costumes, buildings and a peculiar way of life of other peoples, but also the rhythms, lines and colours of local life. The romantic discovery of unusual reality by the artist is traced back to Gauguin and from him to the Russian Futurists. In his desire to make such ethnographical sketches (see in particular his Galician Album of 1915-6 in the collection of the Russian Museum), Lapshin was inspired by the experience of Le-Dantiu, who had brought his Caucasian sketchbooks to St Petersburg in 1912. Although only one of them, the one kept at the Bakhrushin Theatre Museum, is now known, the impression Le-Dantiu's Caucasian works produced on Lapshin was tremendous: "I have drawn my first 'pictures' on that basis". [36]

After joining the regiment, Lapshin introduced himself as a Futurist artist. However, involvement in military operations was of little help in producing works on the war theme in the spirit of Futurism. Personal experiences and observations that Lapshin had always relied upon proved inadequate: "A new problem arose at the frontline: how to depict war when you hear more than see there. There appeared Futurist drawings, in which different lines depict the flight of missiles and seek to convey both the sound of the flight and the explosion, as well as drawings representing simultaneously the field glasses and the enlarged view through them, and firing cannons. $<\ldots>$ At the frontline it was not all that dynamic as Marinetti has it in Tripoli." [37]

Issue 15 (1916) of Bloodless Murder dealt with the evacuation of Lapshin, who had been wounded at the frontline. The issue consists of a hectograph drawing of Lapshin with an inscription underneath: "We came face to 
face at the Dniester, went into combat not far from Halych; with the bullet in the leg I'll have a little rest... But, no evacuation is in store. Why should the nation suffer? Now in a carriage, now in a heated goods van, now in an auto; now to Odessa, now to Siberia, now to Rostov! In a month I was so glad to be back to Petrograd!" [38] The drawing itself is done in Futurist style: dynamic rounded lines divide the sheet into sectors with geometricised shapes inside. Overall, the representation is concretely narrative. A lightning, rain, a carriage, a house, an ear and a self-portrait with a crutch and a Cross of Saint George on the chest are the "microplots" producing a more or less coherent story of the past events. Lapshin also introduces an image of Ancient Egyptian art into the kaleidoscope of the pictures: the sun is stretching out its arms toward the wounded man. Mundane poetry laden in the precise details of the depicted things is combined with typically Futurist or vsyochesky (all sorts of) techniques. Dmitry Sarabianov observed a similar combination in paintings of Lapshin and Georgy Yakulov, due to which he called the latter a "semi-Futurist". [39]

\section{THE LAST ISSUE OF THE MAGAZINE}

Leshkova's letters to Le-Dantiu at the front gave a detailed account of the life of the "Bloodless Murder" coterie of friends. In one of them Leshkova commented on a "collective illustrated epistle" composed at a party at Yermolayeva's in early November 1916. Among other representations she mentioned: "The first picture of wartime life crossed by the 'all-seeing eye' is by Nik.<olai $>$ Iv. $<$ anovich $>$ Strunke $<\ldots>$ a graphic representation of the concert of war by Kolya Lapshin, then Vera Mikh.<ailovna Yermolayeva $>$ flying a Zeppelin". [40] This improvised account in pictures inspired Le-Dantiu to make Issue 17 of Bloodless Murder named "Return to the Bosom". While earlier issues focused on individual members of the group, now the stories of the fifteen of them merged in a large "collage". The hectrograph drawing pictured the past summer events and scenes of "bloodless murderers" returning to Petrograd. The pictures are given in registers or incised one into another with the help of diagonal lines. The faces are recognizable and at the same time ludicrously distorted. Now and then Le-Dantiu mockingly flaunts Futurist techniques by drawing cogwheels inside a cow (Bernstein helping a veterinary) or geometricising the faces of the clergy (Yankin painting the Kronstadt Cathedral). Although Leshkova failed to attribute that illustration in her explanatory note to the issue, it was, beyond doubt, made by Le-Dantiu. [41] A sketch for the composition "Return to the Bosom" and studies of individual characters have survived in his sketchbook. [42] Leshkova also mentioned that drawing in the list of works of Le-Dantiu, drawn up after his death. [43]

That issue happened to be the last one. [44] However, a spectacular finale still lay in store for the Bloodless Murder publishers. The Satyricon magazine published on its front cover a drawing of Vladimir Lebedev in response to two masquerade balls organised by the "bloodless murderers" at Bernstein's studio on 3 December 1916 and 7 January 1917. The keynote of the first ball was the staging of Ilya
Zdanevich's zaum' drama Janko I, the King of Albania, with the sets of "Futurist nature". Leshkova wrote about it: "The audience that passed control numbered 110 people. <..> Nearly the entire audience wore costumes and turned out to be fairly motley in composition, from hereditary titled aristocracy to out-and-out bohemians. $\langle\ldots\rangle$ The entire audience - young people after two and a half years of forced fasting - seemed to have set loose, raved and fooled around, treading on air". [45] "Everybody is offended on behalf of Ilya <Zdanevich>. Lebedev has pushed that central figure of the two soirées somewhere into the background mash. Ilya himself says that it is a 'disg'ace' to be so discou'aging to talent. $<\ldots>$ The sitters' costumes are exaggerated: they were much more decent and beautiful. In general, everything was very stylish, even too stylish, according to Ilya, while Lebedev has turned it into some cesspit. Just the same as a drawing it isn't all that bad, even good for the Satyricon of the past period". [46]

\section{CONCLUSION}

The two grandiose masquerade balls brought the Bloodless Murder history to an end. The life of the publishers, who relied on the "aesthetics of the insignificant", reached its heyday and was cut short. The topic makes a fascinating study by dint of its bright material, as a rare example of the early works of a number of major artists, whose output of the 1910s has for the most part not survived, and as one of the pages of the history of Russian Futurism that is inseparable from the First World War.

\section{REFERENCES}

[1] "Beskrovnoye ubiistvo", № 5. "V tylu" s ob’yasnitelnoi zapiskoi ("In the Rear" with an Explanatory Note), 1915, RGALI, f. 794, op. 1, ed. khr. 185, 1. 4.

[2] "Vera Yermolayeva. 1893-1937", text and commentaries by A. Zainchkovskaya. Moscow: Skorpion, 2009, p. 65.

[3] The acid attacker Vera von Vick, daughter of a Major-General, grew up in the Izmailovsky regiment, in the same area of Rota 1 Izmaylovsky Polk, house 3/5 flat 123 where Olga Leshkova and Mikhail Le-Dantiu lived - another reason for them to pay attention to that case.

[4] Letter of 8 December 1916 // Pis'ma O. I. Leshkovoi M. V. LeDantiu (Letters of O. I. Leshkova to M. V. Le-Dantiu), RGALI, f. 792 op. 3 , d. $16,1.17$

[5] "Beskrovnoye ubiistvo", № 5. "V tylu” s ob’yasnitelnoi zapiskoi ("In the Rear" with an Explanatory Note), 1915, RGALI, f. 794, op. 1, ed. khr. 185, 1. Leaving the magazine aside, let me mention that Leshkova was directly linked with the theatre. In the period under review she worked at the Mariinsky Theatre power station and frequently attended performances. Her brother, Denis Ivanovich Leshkov, was a well-known ballet lover, subsequently headed the State Academic Theatres Department and left behind a book of memoirs (D. I. Leshkov, Parter i kartser. Vospominaniya ofitsera i teatrala (The Stalls and the Lockup. Memoirs of an Officer and Theater-goer). Moscow: Molodaya gvardiya, 2004).

[6] “Beskrovnoye ubiistvo", № 5. "V tylu” s ob’yasnitelnoi zapiskoi ("In the Rear" with an explanatory note), 1915, RGALI, f. 794, op. 1, ed. khr. $185,1.4$.

[7] Letter of 15 February 1917 // Pis'ma O. I. Leshkovoi M. V. LeDantiu (Letters of O. I. Leshkova to M. V. Le-Dantiu), RGALI, f. 792, op. 3 , d.16, 1. 55 . 
[8] See reprint: "Vera Yermolayeva: 1893-1937", text and commentaries by A. Zainchkovskaya. Moscow: Scorpion, 2009, p. 199.

[9] "Beskrovnoye ubiistvo", № 8. Daghestani Issue with explanatory note, n. d., RGALI, f. 794, op. 1, ed. khr. 188, 1. 2.

[10] Letter of 11 November 1916 // Pis'ma O. I. Leshkovoi M. V. LeDantiu, RGALI, f. 792, op. 3, d.16, 1.6 rev.; letter of 15 November 1916 // Ibid., 1. 8; letter of 24 November 1916 // Ibid., 1. 9; letter of 23 December 1916 // Ibid., 1. 29 rev.

[11] Letter of O. I. Leshkova to M. V. Le-Dantiu of 15 November 1916 // Ibid., 1. 8 .

[12] Letter of O. I. Leshkova to M. V. Le-Dantiu of 24 November 1916 // Ibid., 1. 9.

[13] Letter of 9 January 1917 // Pis'ma O. I. Leshkovoi M. V. Le-Dantiu, RGALI, f. 792, op. 3, d.16, 1. 42 rev.

[14] See O. I. Leshkova's explanatory note about the appearance and activities of the "Bloodless Murder" magazine with a list of magazine materials, RGALI, f. 794, op. 1, ed khr. 182., 1. 1.

[15] Letter of 8 December 1916 // O. I. Leshkova's letters to M. V. LeDantiu, RGALI, f. 792, op 3, d. 16, 1. 17.

[16] D. V. Sarabianov, "Vstrecha posle stoletnego pereryva" (Meeting after a Century-long Break) // Avangard i ostalnoie. Collection of article toward the $75^{\text {th }}$ Birth Anniversary of A. E. Parnis, Moscow: Tri kvadrata, 2013, p. 645-646.

[17] Letter of 8 December 1916 // O. I. Leshkova's letters to M. V. LeDantiu, RGALI, f. 792, op 3, d. 16, 1. 18.

[18] N. F. Lapshin // Lapshin Nikolai Fyodorovich. 1891-1942. Moscow: Skorpion, 2005, p. 175.

[19] See address in the letter of 24 November 1916 // O. I. Leshkova's letters to M. V. Le-Dantiu, RGALI, f. 792, op 3, d. 16, 1.9 rev.

[20] Letter of 2 December 1916 // O. I. Leshkova's letters to M. V. LeDantiu, RGALI, f. 792, op 3, d. 16, 1. 15 rev.

[21] J. Lavrin // "Prorocheskaia dusha. V. Khlebnikov v vospominaniyakh sovremennikov. K 100-letiu so dnia rozhdeniya poeta" ("Prophetic Soul. V. Khlebnikov in Memoirs of His Contemporaries. Toward the Poet's Birth Centenary”) // Literaturnoye obozreniye, № 12, 1985, p. 98.

[22] "Beskrovnoye ubiistvo", № 4 with a drawing of M. V. Le-Dantiu; text signed "Aunt Olya" [O. I. Leshkova], 1915, RGALI, f. 794, op. 1, ed. khr. 184, 1.1 rev.

[23] "Beskrovnoye ubiistvo", № 5. "V tylu” (“In the Rear"), RGALI, f. 794, op. 1, ed. khr. 185, 1. 4

[24] "Beskrovnoye ubiistvo", № 6. The Fiji Islands Issue, 1916 // Text prepared and published by N. Gurianova // Iskusstvo, No. 10, 1989, p. 56.

[25] O. I. Leshkova handed over her archive, together with that of her brother D.I. Leshkov, to the State Literary Museum, from where the entire stock was moved to RGALI.

[26] "Beskrovnoye ubiistvo", № 4, 1. 1 rev.

[27] "Getting down to work it is necessary $\langle\ldots>$ to have a firm idea of the rhythm and primarily to seek to express it." (M. V Le-Dantiu, Doklady, stat'yi i zametki o zhivopisi I teatralnom iskusstve, RGALI, f. 792, op. 1, ed. khr. 1, 1. 72. Cit. E. Yudina, "Kavkazskii albom Mikhaila Le-Dantiu" // Terentievskii sbornik, 1996. Moscow: Hylaea, 1996, p. 154)

[28] Letter of M. V. Le-Dantiu to N. F. Lapshin of 14 January 1917 // Excerpts from letters of artists about painting; from letters of M. V. Le-Dantiu to N. F. Lapshin and O. I. Leshkova, 1911-1917, RGALI, f. 792, op. 1, ed. khr. 9, 1. 3.

[29] See "Bich", № 23, 1 June 1914, p. 4

[30] "Beskrovnoye ubiistvo", № 5. "V tylu" ("In the Rear"), RGALI, f. 794, op. 1, ed. khr. 185, 1. 2.

[31] Illustrations to satirical magazines of the WWI period frequently showed queues (queue to a Butcher’s Shop (“Bich”, № 4, 14 Sept. 1916, p. 11); queue to a Skorokhod Shop (caption: "Could they be selling sugar at Skorokhod?" "Bich”, № 11, 2 Nov. 1916, p. 2); queue for a "Bich” magazine subscription for 1917 (“Bich”, № 17, 14 Dec.
1916, p. 14); queue to a Butcher's and Greengrocer's Shop ("Bich", № 18, 25 Dec. 1916, p. 14) et al.

[32] See "New Satyricon”, № 20, 14 May 1915, p. 3.

[33] N. N. Breshko-Breshkovsky, "Dikaya diviziya" ("The Savage Division"). Yekaterinburg, 1994, pp. 11-2. Cit. Iu. A. Gavrilov, A. G. Shevchenko, "Dikaya diviziya" v srazheniyakh Pervoi mirovoi voiny (The Savage Division in First World War Battles) // Arkhiv naslediya - 2004. Moscow, 2006, p. 234.

[34] "From 1844 all the Russian Orders had special versions to be awarded to people of different faiths, where the representation of the Christian saint was replaced with the double-headed eagle." (Iu. A. Gavrilov, A. G. Shevchenko. Op. cit., p. 243)

[35] See "New Satyricon”, № 2, 8 Jan. 1915, p. 4; Ibid., № 3, 15 Jan. 1915 , p. 2; Ibid., № 6, 5 Feb. 1915, p. 6; Ibid., № 9, 25 Feb. 1916, p. 3; Ibid., № 10, 3 Mar. 1916, p. 7; N. F. Lapshin, Album of drawings: 19141916, sheet 22. Horseman. 26 Nov. 1915 (State Russian Museum)

[36] Manuscript of the artist Nikolai Fyodorovich Lapshin Autobiographical Notes. 1941. State Russian Museum Manuscript Department, f. 144, ed. Khr. 452, 1. 40.

[37] Ibid., p. 173. Reference to the "Battle of Tripoli" of F. T. Marinetti.

[38] Lapshin's drawing was published by N. Gurianova, "Bezkrovnoye ubiistvo" // Iskusstvo, № 10, 1989, p. 54.

[39] D. V. Sarabianov. Op. cit, p. 652.

[40] Letter of 7 November $1916 / /$ O. I. Leshkova's letters to M. V. LeDantiu, RGALI, f. 792, op. 3, d. 16, 1. 3.

[41] A. Zainchkovskaya mistakenly attributes it to Yermolayeva ("Vera Yermolayeva. 1893-1937", text and commentaries by A. Zainchkovskaya. Moscow, 2009, p. 197).

[42] RGALI, f. 792, op. 3, ed. khr. 6, 1. 12, 12 rev.

[43] List of pictures and drawings by Mikhail Le-Dantiu drawn up by O. I Leshkova and stating their whereabouts, dated 1919 and undated, RGALI, f. 792, op. 3, ed. khr. 8, 1. 5.

[44] Ilya Zdanevich intended to continue publishing the "Bloodles Murder" and give a boost to its fame, but... "Material has been prepared for the Paris Issue (focussing on Larionov and Goncharova), the Caucasus Issue (focussing on Zdanevich) and for those on other, more public themes. But... the war and revolutionary developments wrought havoc with Zdanevich's plans. A key staff member, the artist Le-Dantiu, was killed in the war, and the others were scattered about by fate, so instead of blooming "Bloodless Murder" floundered." (O. I. Leshkova's explanatory note about the origin and publication of the "Bloodless Murder" magazine with a list of contributions attached, RGALI, f. 794, op. 1, ed. khr. 182, 1. 1).

[45] Letter of 8 December 1916 // O. I. Leshkova's letters to M. V. LeDantiu, RGALI, f. 792, op. 3, ed. khr. 16, 1. 18-18 rev.

[46] Undated letter (second half of January 1917) // O. I. Leshkova's letters to M. V. Le-Dantiu, RGALI, f. 792, op. 3, d. 16, 1. 35-36. 